\title{
A Study of the Relationship between English Culture Teaching and Cultural Confidence in the New Period
}

\author{
Cao Xueping \\ Foreign Language Research Center, Shaanxi Academy of Governance, 710068
}

Keywords: English Culture; Cultural Teaching; Cultural Self-confidence; Cultural Teaching Strategy

\begin{abstract}
Culture is the soul of the nation and the guidance of thought. Since the opening up to the outside world, China's international exchange have been continuously enhanced, and different cultural teachings have been introduced into classroom teaching in China. From many people's perspective that foreign culture teaching will have a certain impact on their own culture, as a result, there are some certain doubts and even resistances to the foreign culture teaching. In this paper, the author briefly expounded the problems existed in the teaching of English culture in the new era, and analyzed the relationship between English culture teaching and cultural self-confidence in the new era and then put forward the effective factors of English culture teaching.
\end{abstract}

There is an inseparable connection between language and culture. Language without culture is empty. Without language, there is no culture. Language is the premise and condition of cultural formation and accumulation, and the development of culture further enriches the connotation of language. In the long history of mankind, human beings use language to create culture, and culture in turn affects humanity. Language and culture together promote the development of human society. Different languages are the expressions of different cultures. Language is often regarded as the carrier of culture. The essence of culture can be described through language.

Since the reform and opening up, China's opening up to the outside world has obviously accelerated, and various foreign civilizations and cultures have flooded into the tide. As the main front of the cultivation of higher talents in China, colleges and universities are unquestionably welcoming all kinds of new trends and the forefront of new culture. As a basic course generally opened in colleges and universities, English will inevitably introduce the introduction of English culture in the teaching process. For a long time, there has always been a questioning voice in the learning of English culture in society. These skeptics are afraid that the study of English culture will have an unpredictable impact on their own culture. Some even promote the study of foreign culture to the level of national security.

\section{Disadvantages of Traditional English Culture Teaching}

In recent years, there have been two voices in the society about the attitude of English culture teaching. From the top policy designers to the underlying policy implementers, the attitude towards this issue is inconsistent. But most people still hold a positive attitude. In the new curriculum reform document, emphasis is placed on the cultural awareness of students. The author believes that the existence of the questioning voice is mainly due to the existing problems in the teaching of English culture in colleges and universities in China. At present, there are mainly the following drawbacks in the teaching of higher English culture in China:

\subsection{The initiative to learn culture is not strong}

Under the traditional education mode in our country, the explanation of knowledge points in English teaching is relatively simple, and it is rarely explained for students to develop a certain knowledge point. Therefore, in the eyes of many students, cultural learning does not help much in their own work. They think that they will not go abroad anyway, and learning English culture does not have realistic meaning. When teachers introduce knowledge about English culture in lectures, 
they often only follow the textbooks, and rarely compare the similarities and differences between Chinese and foreign cultures. Students sometimes feel the difference between the two cultures, but they are not allowed to measure the difference. There is no way to distinguish between the two cultures. At the same time, due to the constraints of the teaching model in our country, students rarely have the opportunity to experience the atmosphere of foreign culture. Over time, they either accept the foreign culture in their entirety or refuse to accept anything about foreign culture, and it is easy to form a one-size-fits-all view. It is not too short to offer English culture courses in higher education in China, but there are not many students who can learn more about English culture through the classroom. This is not only a matter of education and teaching, but also a complex social issue. This issue involves the strategy of education and teaching methods, the attitude of the society to foreign culture, the goal of education and teaching, and so on. It is precisely because of the contradictions that the society, the school and the students are always in a state of constant heat and cold for the study of English culture. The enthusiasm and initiative of students to learn English culture is not high.

\subsection{The teachers have limited knowledge about English}

Under the traditional education and teaching model in our country, teachers are in a dominant position, teachers teaching, and student learning seem to be a matter of course. It is in this mode that the quality of teachers' English culture directly determines the quality of classroom teaching and determines the success or failure of English culture teaching. But unfortunately, on the whole, the English quality of Chinese teachers is generally not high. It is necessary to feel a culture in order to understand it. According to incomplete statistics, only a small number of teachers engaged in English culture teaching in China have experience in studying abroad and truly perceive the English culture atmosphere. Most teachers have relatively simple ways to learn English culture. They only collect texts and pictures and related audio and video materials, listen to English culture courses, and participate in some related training. Under this relatively simple learning path, it is difficult to create a culture that is inclusive and profound. Throughout the college English teacher faculty, there are limited number of teachers who are English major and also proficient in English culture as well as teaching rules. In addition, there are many administrative things in colleges and universities. Many teachers are tired of coping with it. There is very little time and energy to continue their studies. The current level and the level of entry are not very different. The teacher's own limited cultural accomplishment is not good enough for students, which makes the English culture classroom teaching often stay in the form.

\subsection{Cross-cultural awareness is weak}

Undoubtedly, any culture has its own characteristics and advantages and disadvantages. We should not and cannot recognize or deny a certain culture. Therefore, in the teaching of English culture, it is especially important to cultivate students' cross-cultural awareness. However, the current cross-cultural awareness of students is relatively weak. There are three main reasons, and the first is the environmental factor. In English learning in China, students lack a practical pragmatic atmosphere, and learning and application are basically separated. The second is the learning habits. For a long time, many students have used Chinese thinking to learn English, which is quite unfavorable for the cultivation of cross-cultural awareness. The third is the impact of the test-making education. Although the embryonic form of quality education is beginning to appear, the disadvantages of exam-oriented education are still difficult to get rid of in a short period of time. It is difficult for teachers and students to easily get out of the barriers of exam-oriented education. I have heard the mantra of the students: "I am Chinese, why do I study foreign languages? I can still be a person without learning foreign languages!” Under such a concept, cross-cultural awareness is even more difficult to talk about.

\subsection{Teaching evaluation system is relatively simple}

Teaching evaluation is based on the goal of education and teaching. Use scientific and reasonable means to collect teaching information through the system and make fair and objective judgments on 
teaching activities. The evaluation system is both an educational activity and a social activity. At present, the evaluation of English culture teaching in Chinese universities still stays at a lower level, and always tries to describe a complicated process through some simple and digital methods. Although the impact of this evaluation system on English culture teaching is not obvious, it is often fatal. Many students adjust the goal of English culture learning to cope with exams, and there are not many students with this mentality. This damage to English culture teaching is self-evident.

\section{English Culture Teaching and Cultural Self-Confidence}

China is one of the four ancient civilizations. The Chinese civilization has a long history and has always stood in the world with a confident attitude. A distinctive feature of Chinese culture is its inclusiveness and its strengths. Since modern times, we have experienced a history of humiliation. Therefore, many people in China have an instinctive rejection of foreign culture. In the teaching of English culture, we must try to guide students to quit this kind of psychology. Because of our deep cultural heritage, we have the ability to resist the invasion of foreign cultures and the ability to resist foreign cultures. Moreover, today, the global integration of the economy and society has become an irreversible trend. Therefore, it is not feasible to blindly exclude, to stand still and to move against the trend.

At present, the idea of cultural self-confidence further clarifies our attitude towards foreign culture. The core of cultural self-confidence is to stand on the ground, absorb foreign essence, and look into the future. The profound national traditional culture, the scientific Marxist guiding ideology, and the rich revolutionary culture are the foundations for us to settle down. Absorbing foreign culture is a way for us to enrich our cultural connotations and is an inevitable requirement for promoting the prosperity of Chinese culture. When we absorb foreign cultures, we must have an open and inclusive mind, a dialectical attitude, and the ability to transform and rebuild. At the same time, we must look at the world, examine ourselves, and look to the future. We must grasp the prospects of China's cultural development from the development trend of the world, from the practice of socialism with Chinese characteristics, from the good situation of our own cultural construction, and from the trend of networking and informationization. This undoubtedly provides a solid theoretical basis and basis for us to teach English culture.

English culture teaching guided by cultural self-confidence should aim at improving students' cultural appreciation and intercultural communication ability, and is based on cultivating students' cultural awareness. Focusing on cultivating students' independent cultural personality, discarding cultural appreciation, and inclusive and open cultural mentality, they can break through the traditional "Chinese cultural aphasia" at a higher level. Use English as a medium to tell the story of China and spread the voice of China. Ultimately, we will veritable achieve cultural self-confidence.

\section{Effective Factors in English Culture Teaching}

With the deepening of the study of language and culture, the interdependence between language and culture has not been described. The introduction of cultural teaching in language teaching has reached consensus in the foreign language teaching community. According to the latest teaching requirements of college English courses, the fundamental purpose of foreign language teaching in colleges and universities is to cultivate students' practical language skills and improve their comprehensive language literacy. After students have mastered the English grammar to a certain extent, if they can't master the English culture well, they are difficult to use in practical work. The author believes that the effective teaching of English culture in the new era can mainly start from the following aspects:

\subsection{Strengthen the teaching of cultural backgrounds}

Through these years of teaching practice, the author deeply feels that the intensive teaching of cultural background knowledge in English teaching is very important for students' learning. Language is a communicative tool, and the most essential role of language is communication. In the 
past foreign language teaching, we often focused on the teaching of language skills, and the teaching of cultural background knowledge was often relatively neglected. This is why many students show high scores and low energy. On this issue, we must draw enough attention and effectively confuse the mind from anyway. We must embrace English culture with a broad mind, treat English culture with a scientific attitude, and learn English culture with reasonable measures. In terms of curriculum, we must increase the proportion of English culture teaching, so that English culture teaching gradually get rid of the supporting role.

\subsection{Strive to forge a high-quality faculty}

The majority of teachers are engaged in front-line teaching work, forging high-level, high-quality teachers to play a decisive role in the achievement of educational goals. All colleges and universities in China should base their own conditions and take measures as much as possible to improve the comprehensive quality of English culture teachers. For example, a qualified school can assign some teachers to exchange and study abroad on a regular or irregular basis, so that teachers can constantly improve themselves, improve themselves, and promote their knowledge to their own soft power. Or, the school can organize exchanges and learning activities between the inter-school and professional teachers, and the peer teachers can communicate with each other and discuss the things in the cultural teaching. At the same time, English teachers are strongly encouraged to make full use of information resources to watch the original English-American culture teaching videos through video open classes (such as micro-classes, MOOCs, etc.). They can extract the essence and nutrition from them, and constantly improve the internal strength of their own cultural teaching and enrich the connotation of cultural teaching.

\subsection{Introducing national culture teaching in English culture teaching}

It is necessary to break through the traditional "teaching language instead of culture" mode to provide a clear direction for Chinese culture teaching at English classes. Specific contrast teaching methods can be used, such as comparing the reactions of people of different nationalities in the Sino-American cultural atmosphere in the same situation, so that students can understand themselves, respect others and enhance their cultural empathy. At the same time, under the premise of consolidating the basic skills of students, the students are taught many English expressions of Chinese culture to enhance their cultural expression and become active communicators of Chinese culture. Then, they can use English as a medium to tell the Chinese story and spread the Chinese voice.

\section{Conclusion}

Colleges and universities are the main venue for spreading new ideas and creating new cultures, and are important carriers for students to learn cultural knowledge and develop innovative thinking. In the teaching of English culture in colleges and universities, with the guidance of cultural self-confidence, strengthen the teaching of English cultural background knowledge, and strive to build a high-quality college English teacher team. At the same time, the introduction of Chinese culture teaching in English culture teaching is very beneficial to improve students' cultural self-confidence.

\section{References}

[1] Li Hua. Intercultural Teaching and Cultivation of Humanities Quality of English Majors [J]. High Teaching Journal, 2017(14)

[2] Cai Yong. Infiltration of English Culture Education Based on Teaching Materials [J]. English Teachers, 2017(7)

[3] Zheng Xiaolong. Research on College English Culture Teaching from the Perspective of Multiculturalism [D]. Central South University, 2013. 
[4] Yang Yan. Multiculturalism and College English Culture Teaching [J]. Journal of Lanzhou College of Education, 2015, 01:116-117.

[5] Ren Bing. Analysis of the Reform Method of College English Teaching under the Background of Multiculturalism [J].Heilongjiang Higher Education Research,2014,08:171-173.

[6] Tang Wei. Analysis on the Reform of College English Teaching under the Background of Multiculturalism [J].Journal of Jiamusi Vocational College,2016,03:356.

[7] Zhang Youping. Understanding of Language Teaching and Culture Teaching [J]. Foreign Languages, 2003 (3).

[8] Li Yuewen, Chen Yuanyuan. On the Basic Qualities and Cultivation of Foreign Language Teachers in Colleges and Universities [J]. Journal of Mudanjiang University, 2010(6). 